\title{
TEACHING SPEAKING USING SHAKE CHOPSTICKS GAME
}

\author{
Ayu Hartini ${ }^{1}$, Wulan Tripuspita ${ }^{2}$ \\ ${ }^{1}$ IKIP Siliwangi \\ ${ }^{2}$ IKIP Siliwangi \\ ${ }^{1}$ Ayuhartini19@yahoo.co.id , ${ }^{2}$ wulantripuspita01@gmail.com,
}

\begin{abstract}
This study was conducted to improve speaking skill of the first grade at SMP N 1 Pangkalan. The game was proposed in the teaching of speaking, because that is attracting and interesting, especially for students' speaking skill. The improvement of the students' score can be seen in the increased of the students' speaking from the preliminary study (pre-test) and the score after the implementation (posttest) of the teaching speaking using shake chopsticks game. This research used a pre-experiment method by using one group pre-test and post-test design. The subject of this research were VII students of SMP N 1 Pangkalan of the 2017/2018 academic years. The finding showed that the students' score of speaking increased after being taught by using shake chopsticks game. This indicates that the use of shake chopsticks game is effective in improving students' speaking ability.
\end{abstract}

Keywords: Speaking skill, game, shake chopticks game

\section{INTRODUCTION}

The English Language is also considered as an important language to be learned. As supported by Mndriyah and Parmawati (2016) that there are many fields which can be seen dealing with the role of English, such as: technology, health, tourism, correspondence, etc. In Indonesia, English is taught from Elementary School up to University Level. According to Aryana and Apsari (2018), In teaching English, there are four skills such as listening, speaking, reading and writing that must be mastered by a teacher. It means that one of the skills that should be mastered by the students in learning English in speaking. Because speaking is used as a mean of communication between one person to other. Thus, many people want to develop their speaking skill and make sure their children have good English speaking. Absolutely, students have to produce and interact with the language in any aspect of their daily communication. It is because not sufficient for students to learn only words, phrases, and grammatical features if they want to improve their skill.

There is an understanding of speaking according to experts. Argawati (2014) defines Speaking is an activity used by someone to communicate with others it takes place everywhere and has become part of our daily activities. While, Brown (2001) states that when someone can speak a language it means that he can carry on conversation reasonably competently. In addition, he states that the benchmark of successful acquisition of language is almost always the demonstration of an ability to accomplish pragmatic goals through on interactive discourse with other language speakers. The ability to speak fluently presupposes not only a knowledge of language features but also the ability to process information and language on the spot (Harmer, 
2001). Based on three opinions above the writer conclude that speaking is an activity by someone to communicate with other. When someone can speak a language it means that he can carry on conversation reasonably competently. This reality makes a teacher thinks that speaking skill should be improved and be mastered by their students. Students have to develop their communicative skill and student expected to be able in using the English language early. Speaking is used for many different purposes. Each purpose may be to make social contact with people to express opinions, to persuade someone about something or to clarify information. Almost all learner study English in order to develop proficiency in speaking.

However, the ability to speak fluently presupposes not only a knowledge of language features but also the ability to process information and language on the spot. In the school, The Students was poor English speaking skill because some factors fell so bored if learning in the classroom because of the method of learning to monotonous, poor facility of learning activities. In order to minimize those problems, the writer considers that it is necessary to find out an alternative technique to create suitable and interesting teaching. The teacher needs to help students encourage students anxiety, motivate them to learn better especially help the students to overcome the speaking skill problems and they need any practices to assist them in developing their speaking skill. For this reason, many techniques can be applied including game because it encourages the students to be actively participating in teaching learning process and many Research findings say that this technique is effective to use in teaching speaking. The name of this game can be called Shake Chopsticks Game. This technique also gives students an opportunity to practice communicating in different social context and social roles.

Teaching using game is one away for a teacher when teaching in the class. Because with a game the students do not feel bored when learning in the class. According Aqib \& Murtadlo (2016), Game are a media can use for play, with exploring their world from don't know until know without duress elements and without basic responsibility. Based on three opinions above, the writer concludes that the game is media used for playing are designed to provoke communication between students as consisting of rules that describe allowable player moves. Harmer (2001) states game are designed to provoke communication between students. The game is made based on the principle of the information gap so that one student has to talk to a partner in order to solve a puzzle, draw a picture, put a thing in the right order, or find similarities and differences between pictures.

The word "Game" means an activity which is entertaining and engaging, often challenging and activity in which the learners play and usually interact with others (Wright, 2006). While, based on Heap \& Yanis (1995), there are further aspects of the way that game theorists model social interaction which strikes many social scientists as peculiar. The first is the assumption that individuals know the rules of the game that is, they know all the possible actions and how the actions combine to yield particular payoffs for each player. The second and slightly less visible one is that a person's motive for choosing a particular action is strictly independent of the rules of the game which structure the opportunities for a Consider the first peculiarity. According to the theories by expert above the writer summarized that game is an activity which is entertaining and engaging using media for play are designed to provoke communication between students.

According to Aqib \& Murtadlo (2016), Shake Chopsticks Game is a media creations teacher who adopted from the tool is usually used by the Chinese people as one of the media for a forecast. While, the writer summarized more simple that Shake Chopsticks Game is a Game with using Chopsticks as media or material. This game just a traditional game but this game was quite fun to play in the class. It is quite easy to get the tool used to Shake Chopsticks Game. 
There are tools which can be used while playing the Shake Chopsticks Game: Cup/glass (not invisibility) and Chopsticks made from wood (some chopsticks give mark at the end chopsticks example give red mark this chopstick so-called "Lucky Chopsticks").

The writer is interested in researching and analyzing the process of teaching speaking by using Shake Chopsticks Game at the first grade of Junior High School. Can talking about a job, daily activities, hobbies, introducing and other. Because the student poor in English speaking skill and look less enthusiastic about learning English further in speaking because of the monotonous class.

\section{METHOD}

This research used quantitative research method (Muijs, 2004). In addition, the researcher used a pre-experiment method by using one group pre-test and post-test design (Winarno, 2013). Where the writer did an experiment in a single group only to know if there is any significant influence of game on the students' speaking skill. The data from pre-test and post-test will be analyzed to find out whether the result of the tests is similar or different. The writer will analyze data by using SPSS (Statistical Product and Service Solutions) Version 23 will be used to find out the effectiveness of using the game technique to enhance speaking skill. The procedure in this research as follows: Pre-test, Treatment, and Postest. The pre-test was conducted in the first meeting to measure students' speaking skill before treatment. The research gave an oral test. Teacher show some pictures and then student explain the characteristics and appearance of that picture. While the Treatment doing In the classroom the teacher taught to the students about the characteristics and appearance of people, animal, and thing. In this treatment, the writer used Shake Chopsticks Game when learning in the classroom. And the Post-test was conducted in the last meeting to measure students' speaking skill after getting the treatment. The writer gave an oral test again similar to the pre-test. The teacher shows some pictures and then the student explains the characteristics and appearance of that picture.

This research had been held at SMP N 1 Pangkalan. It is located on Jl. Raya Pangkalan Loji Ds. Cinta Laksana Kec. Pangkalan Kab. Karawang Prov. Jawa Barat 41362. It was conducted in the second semester. This research began from January 17th, 2018 until February 08th 2018. The writer chooses VII A for experimental class because the tutor teacher who as an English teacher in SMP N 1 Pangkalan want to the writer for conduct experiment in class VII A academic year 2017/2018. There were 30 students in class VII A. The class consisted of 15 male and 15 female students. They were about 11 to 12 years old. Most of them came from the middle economical background.

\section{RESULTS AND DISCUSSION}

\section{Results}

The writer gave the oral test in pre-test and post-test. The pre-test was given to the students to measure their speaking skill before the treatment while the post-test was given to the students to measure their speaking skill after getting the treatment. The topic of pre-test is about the character and appearance of people, animal, and thing. The topic of post-test is similar with a pre-test that about characteristic and appearance people, animal and thing. Both pre-test and post-test were conducted in duration 1-2 minute per student. During the test, the teacher directly gave some scores based on the rubric prepared for each student. 
The data of the pre-test score and post-test score can be seen in the table below :

Table 1. The Pre-test Score and Post-test Score

\begin{tabular}{|c|c|c|}
\hline \multirow{2}{*}{ Name } & \multicolumn{2}{|c|}{ Score } \\
\hline & Pre-Test & Post-test \\
\hline Student 1 & 72 & 92 \\
\hline Student 2 & 76 & 96 \\
\hline Student 3 & 80 & 96 \\
\hline Student 4 & 64 & 84 \\
\hline Student 5 & 76 & 92 \\
\hline Student 6 & 80 & 84 \\
\hline Student 7 & 68 & 84 \\
\hline Student 8 & 68 & 92 \\
\hline Student 9 & 72 & 80 \\
\hline Student 10 & 80 & 92 \\
\hline Student 11 & 76 & 92 \\
\hline Student 12 & 76 & 80 \\
\hline Student 13 & 80 & 96 \\
\hline Student 14 & 68 & 72 \\
\hline Student 15 & 84 & 88 \\
\hline Student 16 & 76 & 84 \\
\hline Student 17 & 72 & 80 \\
\hline Student 18 & 72 & 96 \\
\hline Student 19 & 68 & 72 \\
\hline Student 20 & 72 & 88 \\
\hline Student 21 & 76 & 88 \\
\hline Student 22 & 68 & 76 \\
\hline Student 23 & 80 & 84 \\
\hline Student 24 & 64 & 80 \\
\hline Student 25 & 84 & 100 \\
\hline Student 26 & 84 & 88 \\
\hline Student 27 & 64 & 80 \\
\hline Student 28 & 84 & 96 \\
\hline Student 29 & 72 & 96 \\
\hline Student 30 & 80 & 88 \\
\hline Total & 2.236 & 2.620 \\
\hline Mean & 74,53 & 87,33 \\
\hline
\end{tabular}

The data shows that the mean is 74,53 the highest score is 84 and the lowest score is 64 . While Post-test after data analyzed, it shows that the mean is 87,33 the highest score is 100 and the lowest score is 72 . From data above an increased originally score 74,53 at pre-test increased to 87,33 at post-test. 
This research analyzes data by using SPSS (Statistical Product and Service Solutions) Version 23002E. This research applied Kolmogorov-Smirnov and Shapiro-Wilk methods in SPSS version 23 software to test the normality of the data. The result of the normality test of the data is presented as follow:

Table 2. Tests of Normality

\begin{tabular}{|l|l|l|l|l|l|l|}
\hline & \multicolumn{3}{|l|}{ Kolmogorov-Smirnov $^{\mathrm{a}}$} & \multicolumn{3}{l|}{ Shapiro-Wilk } \\
\cline { 2 - 7 } & Statistic & $\mathrm{df}$ & Sig. & Statistic & df & Sig. \\
\hline pretest &, 142 & 30 &, 125 &, 931 & 30 &, 053 \\
posttest &, 138 & 30 &, 150 &, 946 & 30 &, 130 \\
\hline
\end{tabular}

a. Lilliefors Significance Correction

From the table 4.2 can be seen that the significance value of the normality test of pre-test score was 0.125 . Therefore, the significance score was higher than $0.05(0.125>0.05)$. it means that Ho was accepted so the data was normality distributed. Meanwhile, the significance of posttest score was 0.150 which means the value was also higher than 0.05 . Based on the criteria the data was normality distributed because the value was higher than $0.05(0.150>0.05)$. in the other words, it can be assumed that the pre-test and post-test are normally distributed.

After conducting normality test and the result showed that the data were normally distributed, the next step of the calculation that must be done was the homogeneity test of pre-test and posttest by using SPSS version 23 software. The calculation which must be done was Levene Statistic. The result of the homogeneity test of the data is presented as follow:

Table 3. Test of Homogeneity of Variances

\begin{tabular}{|l|l|l|l|}
\hline Levene Statistic & df1 & df2 & Sig. \\
\hline 1,003 & 1 & 58 &, 321 \\
\hline
\end{tabular}

The table showed that the significance of Levene Statistic was 1.003 by the significance of the homogeneity test was 0.321 .

The writer using SPSS version 23 to measure the effectiveness using the game technique on students' speaking skill. The paired samples statistics is presented as follow:

Table 4. Paired Sample Test

\begin{tabular}{|c|c|c|c|c|c|c|c|c|c|}
\hline & \multicolumn{5}{|c|}{ Paired Differences } & \multirow[b]{3}{*}{$\mathrm{t}$} & \multirow[b]{3}{*}{ df } & \multirow{3}{*}{\multicolumn{2}{|c|}{ Sig. (2-tailed) }} \\
\hline & \multirow[b]{2}{*}{ Mean } & \multirow{2}{*}{$\begin{array}{l}\text { Std. } \\
\text { Deviati } \\
\text { on }\end{array}$} & \multirow{2}{*}{$\begin{array}{l}\text { Std. } \\
\text { Error } \\
\text { Mean }\end{array}$} & \multicolumn{2}{|c|}{$\begin{array}{l}95 \% \text { Confidence } \\
\text { Interval of the } \\
\text { Difference }\end{array}$} & & & & \\
\hline & & & & Lower & Upper & & & & \\
\hline $\begin{array}{l}\text { Pair } \\
1\end{array}$ & $\begin{array}{l}\text { pretest - } \\
\text { posttest }\end{array}$ & $-12,667$ & 6,651 & 1,214 & $-15,150$ & $-10,183$ & $-10,432$ & 29 & ,000 \\
\hline
\end{tabular}

From the Paired Sample Test above it can be seen that the value of t-test 10.432 and the degree of freedom is 29.

This section described effectively or not Shake Chopsticks Game for increased students' speaking skill. The score was analyzed by using SPSS version 23. Base on research the application of method Shake Chopsticks Game in post-test in teaching speaking is more 
effective than pre-test. Based on the data finding above it was increased to 87,33 from 74,53. While the students' responses about this method showed the strong positive response from the students. They were actively studying in the class. Based on students' opinion this method is fun so the students feel enjoy with the study. It was proven by increasingly students' score in speaking skill. In determining the score, furthermore, the writer used oral rating scale adapted by Brown (2001). The scoring rubric of the test provided a measure of the quality of performance on the basis of some criteria: Grammar, Vocabulary, Content, Fluency, and pronunciation.

\section{CONCLUSION}

Based on the research, the writer concludes that from the result of the analysis of the research, it is proven that the students' score of speaking taught by using shake chopsticks game is increased. This result has answered the research question that the use of shake chopsticks game in teaching speaking is effective.

\section{ACKNOWLEDGMENTS}

This research entitled "teaching speaking using shake chopsticks game" therefore, the writer wants to express gratitude and appreciation as high as to Dr. Irma Savitri Sadikin, M.Pd as Supervisor I, Trisnendi Syahrizal, S.Pd., M.Hum as Supervisor II, all Lectures of Ikip Siliwangi, Endang Basri, S.Pd., M.Pd as Head Master of SMP N 1 Pangkalan, all teachers of Smp N 1 Pangkalan, my lovely parents my mother Imas and my father Uya Sunarya who always support me, my lovely husband Dede Ahyadi who always support me, my brothers and my sisters, all my friends. Finally, thanks are due to all people who have prayed and supported the writer who cannot be mention one by one. May allah blesses them all. I hope this research is useful for the readers and beneficial to the english teaching and learning process. However, I realize that it is far from being perfect, and therefore any criticism, ideas, and suggestion for its improvement will be greatly appreciated.

\section{REFERENCES}

Aqib, Z \& Murtadlo, A. (2016). Kumpulan Metode Pembelajaran kreatif dan inovatif. PT.

Sarana Tutorial Nurani Sejahtera.

Argawati, N. O. (2014). The use of Task-based introduction to improve speaking skill. Bandung: STKIP Siliwangi Bandung.

Aryana, S., \& Apsari, Y. (2018). Analysing Teacher's Difficulties In Teaching Listening. ELTIN JOURNAL, Journal of English Language Teaching in Indonesia, 6(2), 100-106.

Brown, H. D. (2001). Teaching by principles. California: Longman.

Harmer, J. (2001). The Practice of English Language Teaching. longman.

Heap, S,P,H. \& Yanis, V. (1995). Game Theory. London.

Muijs, D. (2004). Doing Quantitative Research in Education. London: Sage Publication. Mundriyah, M., \& Parmawati, A. (2016). Using Think-Pair-Share (Tps) To Improve Students'writing Creativity (A Classroom Action Research in the Second Semester Students of STKIP Siliwangi Bandung). P2M STKIP Siliwangi, 3(2), 84-91.Winarno,M, E. (2013). Metode Penelitian. Malang: Universitas Negeri Malang. Wright, A. (2006). Games for Language Learning. Cambridge. 